УДК 005.591.6:658.821:633.25.013 (477)

DOI: $10.15673 /$ fie.v12i4.1910

Голодонюк О.М.

старший викладач

кафедра маркетингу, підприємництва і торгівлі

E-mail: kaf.mpit@gmail.com

ORCID ID: 0000-0002-0966-2727
Мільчева В.В. аспірант

кафедра маркетингу, підприємництва і торгівлі E-mail: milchewa.v@gmail.com ORCID ID: 0000-0001-8285-8278

Бондарчук Д.О.

студентка 4 курсу факультету менеджменту, маркетингу та логістики

Одеська національна академія харчових технологій

вул. Канатна, 112, м. Одеса, Україна, 65039

E-mail: dashulya.bondarchuk13@gmail.com

ORCID ID: 0000-0002-6452-9128

\title{
МАРКЕТИНГОВІ АСПЕКТИ ІННОВАЦІЙНОГО РОЗВИТКУ ВИНОРОБНИХ ПІДПРИЄМСТВ
}

В статті представлений аналіз ринку виробництва тихих вин в Україні, проведено маркетингове дослідження споживачів, проведено сегментування ринку збуту та розроблені відповідні рекомендації щодо інноваційного розвитку підприємства. В ході аналізу ринку вина України були виявлені як позитивні, так і несприятливі фрактори розвитку. Але, незважаючи на всі негативні тенденції, які не тільки стримують розвиток, але і ліквідують передумови майбутнього зростання, дана галузь залишається перспективною і розцінюється як та, що може успішно розвиватися в майбутньому. 3 метою вибору правильного напряму розвитку для виноробних підприємств було проведено маркетингове дослідження за допомогою анкетування, яке допомогло визначити смакові переваги споживачів. На основі отриманих під час опитування даних, було складено однофакторну карту і розраховано ємність ринку вина і кращого сегмента. Спираючись на проведений аналіз, було запропоновано до впровадження новий вид продукції - фруктове вино і описані основні маркетингові стратегії, рекомендовані до використання при впровадженні запропонованого проекту.

Ключові слова: маркетинг інновацій, інноваційний розвиток, виноробні підприємства, конкурентоспроможність, маркетингове дослідження.

This work is licensed under a Creative Commons Attribution 4.0 International License http://creativecommons.org/licenses/by/4.0/

Постановка проблеми та її зв'язок з важливими науковими та практичними завданнями. Вивчення і аналіз умов функціонування ринку складають одну з найважливіших частин маркетингового дослідження. Його основною задачею є визначення обставин, при яких досягається динамічна відповідність між попитом та пропозицією. Саме тому вивчення попиту проводиться в тісному зв'язку з вивченням пропозиції і цін, що утворюють єдиний ринковий механізм [1].

На даний момент підприємства велику увагу приділяють впровадженню у виробництво інноваційної продукції з метою покращення свого конкурентного становища серед інших виробників [2].

В останні роки кількість прибічників цього напряму суттєво збільшилася, що і підтверджує актуальність даної проблеми.

Аналіз останніх публікацій по проблемі. Проблеми інноваційного розвитку виноробної галузі України досліджено в роботах таких науковців, як I. Агеєва, Д. Басюк, М. Бойко, О. Карташова, О. Нестеренко, В. Осипов, О. Павлова, В. Папп, М. Петри- чко, Т. Постоян, О. Ткаченко, А. Шумський та багато інших. Проте висока актуальність проблеми та різноманітність чинників, що впливають на інноваційний розвиток галузі обумовлюють необхідність подальших глибоких досліджень у цьому напрямі.

Формулювання цілей дослідження. В широкому сенсі слова пі «інновацією» розуміють будьяку зміну в діяльності підприємства, спрямовану на зростання його доходів і більш нормативне використання ресурсів [3].

На даний момент українські виробники фінансують розробку за власний рахунок, тому кожна інновація вимагає якісного маркетингового обгрунтування $[4,5]$.

Виклад основних результатів та їх обгрунтування. До складу виноградарсько-виноробного комплексу України входить виноградарство, промислова переробка винограду, а також виробництва, що обслуговують ці галузі. Кінцевою продукцією комплексу є свіжий виноград, виноградні вина, виноградний сік, коньяки, які виготовляють 3 технічних сортів винограду. 3 відходів переробки одержують різні 
кислоти, дубильні речовини, спирт [6].

Основними виноградарськими областями є Одеська, Херсонська, Миколаївська і Закарпатська. Тут зосереджено понад 90 \% виноградних насаджень України [7].

Згідно з офіційними даним, переробкою винограду, випуском вина, шампанських вин і коньяку займається близько двохсот підприємств України. Серед них чітко вирізняються дві великі групи: традиційні підприємства, що мають власні виноградники, й компанії нової хвилі, що займаються винятково розливом вина. Головний козир останніх - уміле представлення торговельної марки. Якщо оволодіти цим «мистецтвом», то на ринок продукції виноробства можна вийти практично з будь-якого сектору харчової промисловості.

Але, все ж таки, майбутнє галузі за власною сировинною базою. Саме вона гарантує стабільну якість вина.

Дослідження українського ринку вина показує негативні тенденції. Помічено катастрофічне скорочення площ виноградних насаджень та зменшення урожайності винограду. У 2018 році відбулося спрощення процедури отримання ліцензії, що сприяє розвитку малого бізнесу, зменшує монополізацію винного ринку та дозоляє розширити випуск якісної української продукції, заохочує сільськогосподарські підприємства у відновленні та розширенні виноградників та насаджень плодово-ягідних культур [8].

Невирішеним поки що залишається земельне питання. Через відсутність можливості купити землю під виноградники, які почнуть плодоносити лише через п'ять років, не кожен власник готовий інвестувати кошти в цю справу.

Враховуючи всі перераховані тенденції, стан галузі можна констатувати як важкий, а ситуацію на ринку вина охарактеризувати наступними негативними факторами:

- скорочення виробництва виноградного вина;

- збільшення ставок акцизу;

- скорочення виробництва натурального ви-

на;

- велика частка імпортних вин, які надходять до України з Молдови, Угорщини, Грузії та ін. загострюють конкурентну боротьбу на ринку;

- відсутність культури споживання виноградних вин;

- старіння виноградників, дефіцит певних сортів винограду;
- відсутність державної підтримки в умовах економічної нестабільності у вигляді квотування або ліцензування;

- негативна кредитно-фінансова політика, відсутність можливості отримання довгострокових кредитів на розвиток бізнесу.

Отже, розглянуті фактори стримують розвиток виноробної галузі і ліквідують передумови для майбутнього зростання. Але, враховуючи тенденції активного розвитку світового ринку виноробства, зростання споживання вина і посилення конкуренції 3 боку винних країн, питання конкурентоспроможності та можливості процвітання даної галузі України заслуговують на особливу увагу.

Для вивчення пріоритетних напрямів розвитку виноробних підприємств та визначення смакових переваг споживачів було проведено маркетингове дослідження серед покупців вина Одеського регіону.

Було опитано 332 респонденти віком від 21 року, без градації на освіту та фах, оскільки вино не $\epsilon$ продуктом для обмеженої (окрім віку) категорії людей.

Вибіркова сукупність була розрахована за формулою 1 [9]:

$$
n=\frac{t^{2} * \sigma^{2} * N}{t^{2} * \sigma^{2}+\Delta^{2} * N}
$$

де $\mathrm{t}$ - коефіцієнт довіри, залежний від вірогідності твердження, що гранична помилка вибірки не перевищує t-кратну середню помилку (частіше всього $\mathrm{t}=2)$;

$\sigma^{2}$ - дисперсія ознаки, що вивчається, яка визначається на основі експерименту;

$\Delta^{2}$ - гранична (задана) помилка вибірки;

$\mathrm{N}$ - число одиниць в генеральній сукупності.

Опитування показало наступні результати:

$67 \%$ опитаних вживають винну продукцію. Даному напою більше віддають перевагу жінки у віці від 21 до 35 років. 89 \% купують продукцію вітчизняних виробників.

Більшість (44\%) респондентів обирають напівсолодке вино. Ключовим фактором при виборі напою є його натуральність. Ціновий діапазон від 100 до 250 грн. Найголовнішими факторами, на які споживачі звертають увагу в процесі вибору пляшки є ціна та смакові якості. Найчастіше купують у супермаркетах або фірмових винних магазинах.

Спираючись на отримані результати, з метою визначення переважного сегменту, було розроблено однофакторну функціональну карту (табл. 1).

Сегментування ринку збуту вина в м. Одеса*

\begin{tabular}{|l|c|c|c|c|}
\multirow{2}{*}{$\begin{array}{c}\text { Сегменти ринку } \\
\text { за продукцією (i), } \\
\text { (ознака - різновид) }\end{array}$} & \multicolumn{2}{|c|}{$\begin{array}{c}\text { Сегенти ринку за споживачем }(\mathrm{j}), \\
\text { (ознака - рівень доходів) }\end{array}$} & $\begin{array}{c}\text { Структура споживання } \\
\text { (попиту), \% }\end{array}$ \\
\cline { 2 - 4 } & $\begin{array}{c}\text { низький } \\
(\mathrm{j}=1)\end{array}$ & $\begin{array}{c}\text { середній } \\
(\mathrm{j}=2)\end{array}$ & $\begin{array}{c}\text { високий } \\
(\mathrm{j}=3)\end{array}$ & 24,0 \\
\hline 1. Напівсухе $(\mathrm{i}=1)$ & 33,7 & 25,6 & 11,5 & 11,0 \\
\hline 2. Сухе (i=2) & 11,2 & 8,5 & 14,1 & 44,0 \\
\hline 3. Напівсолодке (i=3) & 41,6 & 48,8 & 41,1 & 21,0 \\
\hline 4. Солодке $(\mathrm{i}=4)$ & 13,5 & 17,1 & 33,3 & 100 \\
\hline Частка сегменту за споживачем $\left(\mathrm{d}_{\mathrm{j}}\right), \%$ & 36 & 33 & 31 & \\
\hline
\end{tabular}

* Складено авторами на основі результатів опитування 
Із даних таблиці 1 видно, що перевага надається напівсолодкому вину, яке $є$ найбільш привабливими для споживачів. Тому, саме цей сегмент $є$ переважними для виробництва.

Смність ринку вина м. Одеса була розрахована за наступною формулою [1]:

$$
\mathrm{C}=\mathrm{ЧH}_{\mathrm{H}} * \mathrm{a} * \mathrm{~b} * \mathrm{c} * \mathrm{IC \Pi} * \mathrm{~m} * \mathrm{~T}
$$

де: ЧН - чисельність населення;

a - частка осіб, які не споживають даний товар в силу дії особливих

факторів;

b - частка осіб, старші за 21 рік;

c - частка осіб, які надають перевагу вітчизняному виробнику;

ICП - інтенсивність споживання продукту;

$\mathrm{m}$ - маса разового споживання продукту;

$\mathrm{T}$ - період часу, за який визначається ємність ринку.

$$
\epsilon_{\text {ц.р. }}=1015 * 0,75 * 0,86 * 0,88 * 0,79 * 0,25 * 52=
$$
5916,7 тис.Л. (5916,7 тис. дал)

Отже, річний обсяг ринку вина в м. Одеса складає 5916,7 тис. дал. На основі даного показнику можна розрахувати ємність ринку переважного сегменту:

$€=5916,7$ тис. дал $* 0,44 * 0,28=728,9$ тис. дал

Проаналізувавши ринок винної продукції, провівши маркетингове дослідження споживачів та вивчивши їх смакові переваги дійшли висновку, що для покращення діяльності виноробного підприємства на ринку доцільним буде впровадження нового виду продукції, а саме фруктового вина під торговою маркою «SVONETTY» - «Спробуй раз - полюби назавжди!»

До уваги покупців буде представлено апельсинове вино, до складу якого буде входити апельсиновий сік, що придасть незвичність смаку.

У порівнянні 3 конкурентами, дане вино буде задовольняти потреби споживачів у більшому обсязі, адже він матиме наступні переваги:

- новітня технологія 3 переробки апельсину та спеціального методу бродіння для досягнення бездоганного смаку;

- унікальна упаковка із зображенням апельсину та шматочками сушеного фрукту у подарунок;

- неповторний літній свіжий смак.

Виходячи 3 розрахунків, встановлено, що споживачі надають перевагу винній продукції зі смаковими особливостями. Саме тому новий продукт буде виготовлятись із фрукту.

Оскільки апельсини не притаманні нашому середовищу, будуть налагоджені поставки 3 країнімпортерів на вигідних умовах, але через це ціна за пляшку такого вина буде становити 120-150 грн за пляшку.

Упаковка для вина буде мати наступний вигляд (рис. 1). За основу взято традиційну скляну пляшку. На ній розміщена етикетка 3 зображенням соковитого апельсину. Основний об'єм пляшки - 0,75 л, згідно результатів маркетингового дослідження. Пляшка буде запакована в картону коробку, де і зберігатиметься сушений апельсин.

Рис. 1. Макет пляшки апельсинового вина TM «SVONETTY»* * розроблено авторами

Для ціноутворення обираємо мікс стратегії престижних цін та диференційованих психологічних цін. Товар буде пропонуватись на ринку за цінами, що будуть свідчити про престижність даного продукту на ринку та його високу якість.

Для просування даної продукції на ринок ре- 
комендується скористатися наступними маркетинговими комунікаціями:

1. Реклама. Для проведення рекламної кампанії обираємо декілька їі видів в залежності від розміщення - на банерах та інтернет-реклама у відомих соціальних мережах, порталах (YouTube, Facebook, Instagram) з використанням налаштувань показів реклами в залежності від регіону, віку, статі.

2. Засоби стимулювання збуту. Після того, як рекламна кампанія буде запущена, для підвищення зацікавленості споживачів застосовуємо проведення презентацій та дегустацій вина.

3. PR. Для формування позитивного іміджу бренду у свідомості споживачів використаємо один із сучасних різновидів PR-пост з фото чи відео звертання з відгуком про товар на сторінках відомих особистостей у соціальних мережах.

Період проведення усіх заходів для просування - 3 місяці.

Таблиця 2

Плановий бюджет просування продукції на ринок України *

\begin{tabular}{|l|c|c|c|}
\hline \multicolumn{1}{|c|}{ Назва заходу } & $\begin{array}{c}\text { Вартість за 1 про- } \\
\text { ведення, тис. грн. }\end{array}$ & $\begin{array}{c}\text { Кількість разів прове- } \\
\text { дення за період просу- } \\
\text { вання }\end{array}$ & $\begin{array}{c}\text { Сумарна вартість заходу, } \\
\text { тис. грн. }\end{array}$ \\
\hline $\begin{array}{l}\text { Реклама на банерах } \\
(1 \text { місяць) }\end{array}$ & 4 & 500 & 2000 \\
\hline $\begin{array}{l}\text { Інтернет-реклама } \\
\text { (10 тис. показів) }\end{array}$ & 1,2 & 2000 & 1200 \\
\hline $\begin{array}{l}\text { Проведення презентацій та дегу- } \\
\text { стацій }\end{array}$ & 1 & 500 & 500 \\
\hline $\begin{array}{l}\text { Пост 3 відгуком у блогера (500 } \\
\text { тис. підписників і більше) }\end{array}$ & 7 & 15 & 105 \\
\hline Реклама у ютубі & 30 & 5 & 150 \\
\hline Загальна вартість : & \multicolumn{3}{|l}{} \\
\hline
\end{tabular}

* Складено авторами

Отже, загальні витрати на рекламну компанію складуть 3955 тис. грн.

Для оцінки ефективності від рекламної діяльності доцільно розрахувати значення показника ROMI (формула 3) [10].

$$
\begin{gathered}
\text { ROMI }=\frac{\text { Прибуток }- \text { Витрати на рекламу }}{\text { Витрати на рекламу }}= \\
=\frac{17975,58-3955}{3955}=3,54
\end{gathered}
$$

Отримане значення більше за 0 , що свідчить про фінансову вигоду від запропонованого маркетингового бюджету на рекламну кампанію, а також є доцільним і рентабельним для підприємства.

Висновки та перспективи подальших досліджень. Таким чином, спираючись на вищесказане, можна підвести підсумок, що основними заходами, які сприятимуть подальшому розвитку ринку продукції виноробства $\epsilon$ впровадження у виробництво інновацій. В даному випадку, це можуть бути як виробництво нової продукції, так і впровадження новітніх технологій, зміна рецептури, придбання нового обладнання тощо [10].

У ході роботи було запропоновано до впровадження нове фруктове вино. Науковою новизною даного дослідження є проведення аналізу та розробка рекомендацій щодо покращення інноваційної діяльності виноробних підприємств.

Практична значущість одержаних результатів полягає в розробці практичних рекомендацій щодо покращення конкурентоспроможності підприємства шляхом впровадження у виробництво інноваційних продуктів та обгрунтуванні доцільності запропонованих заходів.

\section{Література}

1. Федулова Л.І. Інноваційна економіка: підручник. К. : Либідь, 2006. 480 с.

2. Сиротинська Н.М. Види інноваційних підприємств промисловості // Вісник національного університету Львівська політехніка: Менеджмент та підприємництво в Україні: етапи становлення і проблеми розвитку. Львів: Львівська політехніка. 2012. № 727. С.314-319.

3. Македон В. В., Рубець Д. С. Стратегічний інноваційний розвиток підприємств: теорія та методологія // Вісник НТУ «Харківський політехнічний інститут». 2013. № 45 (1018). С. 75-86.

4. Gosnar Ana. The Classification of Innovations: the Case of Apple Inc. University of Ljubljana, Faculty of Economics, 2012. 64 p. URL: http://www.cek.ef.uni-lj.si/magister/gosnar795-B.pdf (retrieved: 20.10.2020)

5. Kalaman O., Volodina O., Mandrikin D. Innovative development strategy formation of the modern enterprise // Food Industry Economics. 2018. Vol.10. Issue 2. P. 75-82. doi: 10.15673/fie.v10i2.963

6. Агеєва I.М., Агаркова О.В. Дослідження стратегій розвитку на підприємствах виноробної галузі // Економіка харчової промисловості. 2017. Т. 9, Вип. 4. С. 35-42. doi: 10.15673/fie.v9i4.741 
7. Durbalova N., Sedikova I. Strategic management competitive potential of the enterprise // Food Industry Economics. 2019. Vol.11, Issue 4. P. 58-64. doi: 10.15673/fie.v11i4.1547

8. Бойко В., Аверчева Н., Бойко Л. Виноградарсько-виноробна галузь України - перспективний напрям агробізнесу // Економіка АПК. 2019. №3. С. 61. doi: 10.32317/2221-1055.201903061

9. Пархоменко В.М. Методи вибіркових обстежень: навч. посібн. К.: КНУ ім. Тараса Шевченка, 2001. $148 \mathrm{c}$.

10. Университет InSales. Как посчитать ROI и оценить эффективность рекламы / Университет InSales. URL: https://www.insales.ru/blogs/university/roi (дата звертання: 20.10.2020)

11. Bondarenko S., Lagodienko V., Sedikova I., Kalaman O. Application of Project Analysis Software in Project Management in the PreInvestment Phase//Journal of Mechanical Engin eering and Technology. 2018. Vol.9. Is.13. P. 676-684.

12. 15 Of The Most Effective Wine Marketing Tactics: web-site. URL: https://marketing.sfgate.com/blog/15of-the-most-effective-wine-marketing-tactics (retrieved: 20.10.2020)

Стаття надійшла 24.10.2020

Стаття прийнята до друку 8.11.2020 Доступно в мережі Internet 29.12.20

Голодонюк О.М.

старший преподаватель

кафедра маркетинга, предпринимательства и торговли

E-mail: kaf.mpit@gmail.com ORCID ID: 0000-0002-0966-2727

Бондарчук Д.О.

студентка 4 курса фракультета менеджмента, маркетинга и логистики Одесская национальная академия пищевых технологий ул. Канатная, 112, г. Одесса, Украина, 65039 E-mail: dashulya.bondarchuk13@gmail.com ORCID ID: 0000-0002-6452-9128

\section{МАРКЕТИНГОВЫЕ АСПЕКТЫ ИННОВАЦИОННОГО РАЗВИТИЯ ВИНОДЕЛЬЧЕСКИХ ПРЕДПРИЯТИЙ}

В данной статье представлен анализ рынка производства тихих вин Украины, проведено маркетинговое исследование потребителей, проведено сегментирование рынка сбыта, а также разработаны соответственные рекомендации относительно инновационного развития предприятия.

Современное состояние агропромышленного сектора Украины в последнее время остро нуждается в программах научных исследований, которые будут активно способствовать эффективному развитию аграрной сферы и виноградарско-винодельческого производства, также отечественной экономике в целом. Отрасль требует не только внедрения эфффективных экономических механизмов управления, но и постоянной государственной поддержки. Это формируется при правильном использовании основных составляющих инновационной среды, а именно природных, технологических и организационных фракторов, способствующих повышению эффективности виноградарсковинодельческого производства. Необходимо отметить, что винодельческая отрасль выступает как одна из основных отраслей экономики страны и в данный момент нуждается в инновационном развитии поскольку находится состоянии затянувшегося экономического кризиса.

В ходе анализа рынка вина Украины были выявлены как позитивные, так и неблагоприятные факторы развития. Но, несмотря на все негативные тенденции, которые не только сдерживают развитие, но и ликвидируют предпосылки будущего роста, данная отрасль остается перспективной и расценивается как та, что может успешно развиваться в будущем.

С целью выбора правильного направления развития для винодельческих предприятий было проведено маркетинговое исследование с помощью анкетирования, которое помогло определить вкусовые предпочтения потребителей.

На основе полученных во время опроса данных, было составлено однофакторную карту и рассчитано емкость рынка вина и предпочтительного сегмента. 
Опираясь на проведенный анализ, было предложено к внедрению новый вид продукции фрруктовое вино и описаны основные маркетинговые стратегии рекомендуемые к использованию при внедрении предложенного проекта.

Ключевые слова: маркетинг инноваций, инновационное развитие, винодельческие предприятия, конкурентоспособность, маркетинговое исследование.

\author{
Holodonyuk 0. \\ Assistant \\ Milcheva V. \\ Postgraduate \\ Department of Marketing, Business and Trade \\ E-mail: kaf.mpit@gmail.com \\ ORCID ID: 0000-0002-0966-2727 \\ Department of Marketing, Business and Trade \\ E-mail: milchewa.v@gmail.com ORCID ID: \\ 0000-0001-8285-8278
}

Bondarchuk D.

The student of the fourth grade of Management, Marketing and Logistics Faculty

Odessa National Academy of Food Technologies

Kanatna str., 112 Odesa, Ukraine, 65039

E-mail: dashulya.bondarchuk13@gmail.com

ORCID ID: 0000-0002-6452-9128

\title{
MARKETING ASPECTS OF INNOVATIVE DEVELOPMENT OF WINEMAKING ENTERPRISES
}

This article presents the analysis of the market for the production of still wines in Ukraine, conducts a marketing study of consumers, segments the sales market, and develops appropriate recommendations regarding the innovative development of the enterprise.

Recently, the current state of the agro-industrial sector in Ukraine is in dire need of research programs that will actively contribute to the effective development of the agricultural sector and viticulture and wine production, as well as the domestic economy as a whole. The industry requires not only the introduction of effective economic management mechanisms, but also constant state support. This is formed with the correct use of the main components of the innovation environment, namely, natural, technological and organizational factors that contribute to increasing the efficiency of viticulture and wine production. It should be noted that the wine industry acts as one of the main sectors of the country's economy and currently needs innovative development since it is in a state of protracted economic crisis.

During the analysis of the Ukrainian wine market, both positive and negative development factors were identified. But, despite all the negative trends that not only restrain development, but also eliminate the prerequisites for future growth, this industry remains promising and is regarded as one that can successfully develop in the future.

In order to choose the right direction of development for wineries, a marketing research was carried out using a questionnaire, which helped to determine the taste preferences of consumers.

Based on the data obtained during the survey, a one-factor map was drawn up and the capacity of the wine market and the preferred segment was calculated.

Based on the analysis, a new type of product was proposed for implementation - fruit wine and the main marketing strategies recommended for use in the implementation of the proposed project were described. research.

Key words: marketing of innovations, innovative development, wineries, competitiveness, marketing

\section{References}

1. Fedulova, L. (2006). Innovatsiina ekonomika. Kyiv: Lybid.

2. Syrotynska, N. (2012). Vydy innovatsiinykh pidpryiemstv promyslovosti. Visnyk Natsionalnoho Universytetu Lvivska Politekhnika. Menedzhment Ta Pidpryiemnytstvo v Ukraini: Etapy Stanovlennia i Problemy Rozvytku. Lviv: Lvivska Politekhnika, (727), 314-319.

3. Makedon, V., \& Rubets, D. (2013). Stratehichnyi innovatsiinyi rozvytok pidpryiemstv: teoriia ta metodolohiia. Visnyk NTU «Kharkivskyi Politekhnichnyi Instytut», (45 (1018), 75-86.

4. Gosnar, A. (2012). The Classification of Innovations: the Case of Apple Inc. University of Ljubljana, Faculty of Economics. Retrieved October 20, 2020, from http://www.cek.ef.uni-lj.si/magister/gosnar795-B.pdf

5. Kalaman O., Volodina O., \& Mandrikin, D. (2018). Innovative development strategy formation of the modern enter-prise. Food Industry Economics. 10(2), 75-82. doi: 10.15673/fie.v10i2.963 
6. Aheieva, I., \& Aharkova, O. (2017). Doslidzhennia stratehii rozvytku na pidpryiemstvakh vynorobnoi haluzi. Ekonomika Kharchovoi Promyslovosti, 9(4), 35-42. doi: 10.15673/fie.v9i4.741

7. Durbalova N., \& Sedikova I. (2019). Strategic management competitive potential of the enterprise. Food Industry Economics, 11(4), 58-64. doi: 10.15673/fie.v11i4.1547

8. Boiko V., Avercheva N., \& Boiko L. (2019). Vynohradarsko-vynorobna haluz Ukrainy - perspektyvnyi napriam ahrobiznesu. Ekonomika APK, (3), 61. doi: 10.32317/2221-1055.201903061

9. Parkhomenko, V. (2001). Metody vybirkovykh obstezhen. Kyiv: KNU im. Tarasa Shevchenka.

10. Universitet InSales. Kak poschitat ROI i otsenit effektivnost reklamyi. Universitet InSales. Retrieved October 20, 2020, from https://www.insales.ru/blogs/university/roi

11. Bondarenko S., Lagodienko V., Sedikova I., \& Kalaman O. (2018). Application of Project Analysis Software in Project Management in the PreInvestment Phase. Journal of Mechanical Engineering and Technology, 9(13), 676-684.

12. 15 Of The Most Effective Wine Marketing Tactics. Retrieved October 20, 2020, from https://marketing.sfgate.com/blog/15-of-the-most-effective-wine-marketing-tactics

Received 24 October 2020

Approved 8 November 2020

Available in Internet 29.12.2020

Цитування згідно ДСТУ 8302:2015

Голодонюк О.М., Мільчева В.В., Бондарчук Д.О. Маркетингові аспекти інноваційного розвитку виноробних підприємств // Економіка харчової промисловості. 2020. Т.12, вип. 4. С. 41-47. doi: 10.15673/fie.v12i4.1910

Cite as APA style citation

Holodonyuk, O., Milcheva, V., \& Bondarchuk D. (2020). Marketing aspects of innovative development of winemaking enterprises. Food Industry Economics, 12(4), 41-47. doi: 10.15673/fie.v12i4.1910 